\title{
Both complete clearing and thinning of invasive trees lead to short-term recovery of native riparian vegetation in the Western Cape, South Africa
}

\author{
Sheunesu Ruwanza, Mirijam Gaertner, Karen J. Esler \& David M. Richardson
}

\author{
Keywords \\ Biological invasions; Non-native plants; \\ Restoration; Riparian ecosystems; Species \\ composition \\ Nomenclature \\ Goldblatt \& Manning (2000); Bromilow (2010) \\ for all plant species \\ Received 12 March 2012 \\ Accepted 20 June 2012 \\ Co-ordinating Editor: David Ward
}

\begin{abstract}
Ruwanza, S. (corresponding author, sheunesu@sun.ac.zaor ruwanza@yahoo.com), Gaertner, M. (gaertnem@sun.ac.za) \& Richardson, D.M. (rich@sun.ac.za): Department of Botany and Zoology, Centre for Invasion Biology, Stellenbosch University, Private Bag X1, 7602, Matieland, South Africa

Esler, K.J. (kje@sun.ac.za): Centre for Invasion Biology, Department of Conservation Ecology and Entomology, Stellenbosch University, Private Bag X1, 7602, Matieland, South Africa
\end{abstract}

\begin{abstract}
Questions: Most rivers in the Western Cape Province of South Africa are heavily invaded by alien trees, often resulting in profound changes in biodiversity and ecosystem functioning. Although large-scale management operations are underway to clear invasive trees and restore ecosystem function, little is known regarding native species recovery after alien clearing. Has Eucalyptus invasion along the Berg River altered the distribution and composition of native vegetation? How does the removal of invasive trees through complete clearing and thinning facilitate the recovery of native vegetation?
\end{abstract}

Location: Berg River, Western Cape, South Africa.

Methods: We assessed the recovery of native vegetation after $4 \mathrm{yr}$ of complete clearing of the invasive tree Eucalyptus camaldulensis (100\% alien cover removal) and thinning (40-50\% alien cover removal) along the Berg River in the Western Cape, South Africa. Native and alien plant cover, species richness and diversity were recorded on completely cleared and thinned sites and compared to natural (non-invaded control sites) and E. camaldulensis invaded sites.

Results: Species richness and diversity were significantly higher in both completely cleared and thinned sites compared to natural and invaded sites. Increases in species richness and diversity in completely cleared and thinned sites were a result of re-invasion by alien herbaceous and graminoid species, which have the potential to hinder native species recovery. Cover of native trees and shrubs was higher in both completely cleared and thinned sites compared to invaded sites. Species composition (relative cover) in completely cleared and thinned sites was similar to species composition in natural sites.

Conclusions: Both complete clearing and thinning methods promote indigenous vegetation recovery and a positive trajectory towards recovery of ecosystem structure and composition can be expected in future. To improve management operations, a four-stage thinning process that has the potential to facilitate native species recovery is suggested.

\section{Introduction}

Riparian systems worldwide provide a wide array of ecosystem services and functions, which include the provision of food to aquatic habitats, provision of a buffer zone that filters sediments and controls nutrients, and stabilization of stream banks (Hood \& Naiman 2000). However, riparian systems are highly susceptible to invasion by alien plants because of their dynamic hydrology and because rivers act as conduits for the efficient dispersal of propagules (Richardson et al. 2007).

In South Africa, riverbanks and riverbeds are amongst the most densely invaded landscape features (Richardson $\delta$ Van Wilgen 2004), with the most damaging invaders in many areas being Australian Acacia and Eucalyptus species (Richardson \& Van Wilgen 2004; Galatowitsch \& Richardson 2005). Some of these riparian invaders transform natural ecosystems by reducing streamflow, altering 
biogeochemistry, sediment dynamics and channel form, and outcompeting indigenous vegetation (Richardson $\delta$ Van Wilgen 2004). At our study site, the most widespread and abundant invasive alien tree is Eucalyptus, which forms a dense overstorey canopy and a thick litter layer known to suppress germination and growth of other species (Bernhard-Reversat 1999). Suppression by eucalypts has been linked to different causes, such as allelopathy (Zhang et al. 2010) and resource competition (Van Andel \& Aronson 2012). A few remnants of native species are still present in the understorey vegetation. Recognition of the various severe impacts caused by invasive plants in riparian zones led to initiation of one of the world's largest restoration programmes to clear watersheds of invasive trees in 1995: the Working for Water programme (WfW; Esler et al. 2008; Van Wilgen et al. 2011).

Working for Water, with its joint aims of enhancing ecological integrity, water security and social development, has been operating under the assumption that its target ecosystems, mostly riparian, would 'self-repair' once the main stressor (dense stands of invasive alien trees) had been removed (Van Wilgen et al. 1998; Esler et al. 2008). Since the inception of WfW, several studies have addressed localized impacts of clearing invasive trees on natural resources and have shown positive effects of clearing riparian ecosystems. Dye \& Poulter (1995) and Prinsloo \& Scott (1999) found a substantial increase in streamflow after clearing invasive species from riparian areas. Also, Samways \& Taylor (2004) reported that dragonfly populations recovered rapidly after invasive plants were cleared. However, the assumption that these ecosystems 'selfrepair' once the main stressor is removed has remained largely untested (Esler et al. 2008; Holmes et al. 2008). Furthermore, clearing activities can also have negative effects, such as soil erosion and/or secondary invasions (Galatowitsch \& Richardson 2005; Reinecke et al. 2008). Consequently, there is a clear need to consider strategies that produce the desired positive outcomes, namely recovery of native vegetation and ecosystem structure and function, with minimum negative outcomes.

The few studies that have tested the 'self-repair' assumption have focussed on recovery after complete clearing (Galatowitsch \& Richardson 2005; Beater et al. 2008). Others have tested different clearing strategies (Blanchard \& Holmes 2008) and the benefits of active restoration (Pretorius et al. 2008). Little attention has been devoted to the recovery of native riparian vegetation after alien thinning (selective removal of trees). This strategy has been suggested as a means of achieving the main aims of clearing operations while minimizing negative effects associated with total clearing (Van Wyk et al. 1995; Geldenhuys 1997). Effects of thinning on native understorey recovery have been shown to be complex, with responses varying by species or functional group (Moore et al. 2006). Potential advantages of thinning include the increase in resource availability to native understorey vegetation (Gundale et al. 2005), which consequently increases productivity and diversity (Moore et al. 2006; Nelson et al. 2008). However, increases in resource availability could exacerbate competition by other invasive species, leading to reduced plant diversity of native understorey vegetation (Huston 1979). Soil disturbances associated with thinning operations (even with complete clearing) are also likely to enhance the proliferation of alien species (Bailey et al. 1998), thus negatively influencing native species diversity. Regardless of these constraints, observations of responses of native vegetation to thinning in tree plantations in South Africa have led to suggestions that thinning may be an appropriate strategy for managing riparian zones invaded by alien trees (Van Wyk et al. 1995; Geldenhuys 1997).

Whether thinning, complete clearing or even further management interventions such as active restoration are needed depends on the degree of ecosystem degradation. Plant invasions can reduce ecosystem resilience by altering community composition and structure and by changing ecosystem functioning (Gaertner et al. 2012). If key thresholds have been crossed and resilience has been reduced, the ecosystem will not be able to recover unaided and further interventions will be required to initiate ecosystem recovery (Hobbs \& Harris 2001; King \& Hobbs 2006).

We assessed the recovery of native vegetation after $4 \mathrm{yr}$ of complete alien clearing and thinning of invasive Eucalyptus species (mainly E. camaldulensis) along the Berg River in South Africa's Western Cape Province. To our knowledge this is the first study to compare recovery of native species on both completely cleared and thinned sites following alien overstorey removal. We asked two key questions:

- Has Eucalyptus invasion along the Berg River altered the distribution and composition of native vegetation?

- How does the removal of invasive trees through complete clearing and thinning facilitate the recovery of native vegetation?

\section{Methods}

\section{Study site}

The study was conducted on the upper catchment of the Berg River north of Cape Town in South Africa's Western Cape Province (Fig. 1). The river, approximately 294-km long with a catchment area of about $7715 \mathrm{~km}^{2}$, flows into the Atlantic Ocean at Velddrif (De Villiers 2007). The geology of the upper Berg River catchment is dominated by 
sandstone and quartzites of the Cape supergroup, whereas the rest of the catchment is underlain with Cape granites and Malmesbury Shale (De Villiers 2007). The catchment is characterized by nutrient-poor lithologies, but some areas consist of deep alluvial 'floodplains' with fertile sediments (De Villiers 2007). Almost 50\% of the catchment area is cultivated agricultural land, typical of renosterveld, which is ecotonal to fynbos and succulent karoo. River flow peaks during the winter rainy season, from June to August, with rainfall averaging between 300 and $600 \mathrm{~mm}$ per annum (Mucina \& Rutherford 2006). The whole river stretch is heavily invaded by alien trees, mainly E. camaldulensis, with less abundant stands of other invasive alien plants, notably Acacia longifolia, Acacia mearnsii and Populus species. Native species, e.g. Kiggelaria africana, Olea europaea and Searsia angustifolia, only remain in a few remnant individuals (Geldenhuys 2008). Invasion of the Berg River by E. camaldulensis appears to have started about 50 yr ago; however, knowledge of how eucalypts were introduced is scarce (Geldenhuys 2008). No studies have reported on the pre-invasion conditions of the Berg River.

\section{Site identification}

Four treatments comprising completely cleared sites (CCS) - areas where E. camaldulensis stands were completely harvested in late 2005 and early 2006; thinned sites (TS) - areas where E. camaldulensis stands were selectively (partially) harvested between late 2005 and early 2006; invaded sites (IS) - areas predominantly invaded by E. camaldulensis stands with cover of above $65 \%$; and natural sites (NS) - areas where stands of native species still exist, were selected along the Berg River.

Clearing operations on CCS involved the felling of alien trees (both Eucalyptus and any other existing aliens) and herbicide application on cut stumps to prevent re-sprouting. Felled materials were stacked and burned on site. Follow-up treatments were applied every 4-6 mo for $3 \mathrm{yr}$ after the initial clearing, with the purpose of removing all alien saplings. During the same year, mature E. camaldulensis trees (approximately 30-m high and 40-cm diameter at breast height) were harvested for commercial purposes in TS. In early 2010 we estimated the thinning percentage by counting the tree stumps and compared them to the remaining trees at each site. Using the stump counting method we estimated E. camaldulensis thinning removal to be between $40-50 \%$, which concurred with information from the WfW managers who administered both complete clearing and thinning. No alien clearing follow-up treatments were done on TS. Sites with dense E. camaldulensis canopy cover $(>65 \%)$ were identified and used as IS, whilst sites dominated by native species were identified and used as reference NS. All four treatments were each replicated three times $(n=12)$ and were located between Hermon $\left(33^{\circ} 26^{\prime} 20.76^{\prime \prime} \mathrm{S}, 18^{\circ} 57^{\prime} 28.80^{\prime \prime}\right.$ E) and Franschhoek $\left(33^{\circ} 54^{\prime} 37.44^{\prime \prime}\right.$ S, $19^{\circ} 6^{\prime} 35.64^{\prime \prime}$ E) (Table 1, Fig. 1). Our sites were at least $200 \mathrm{~m}$ apart to provide a measure of independence.

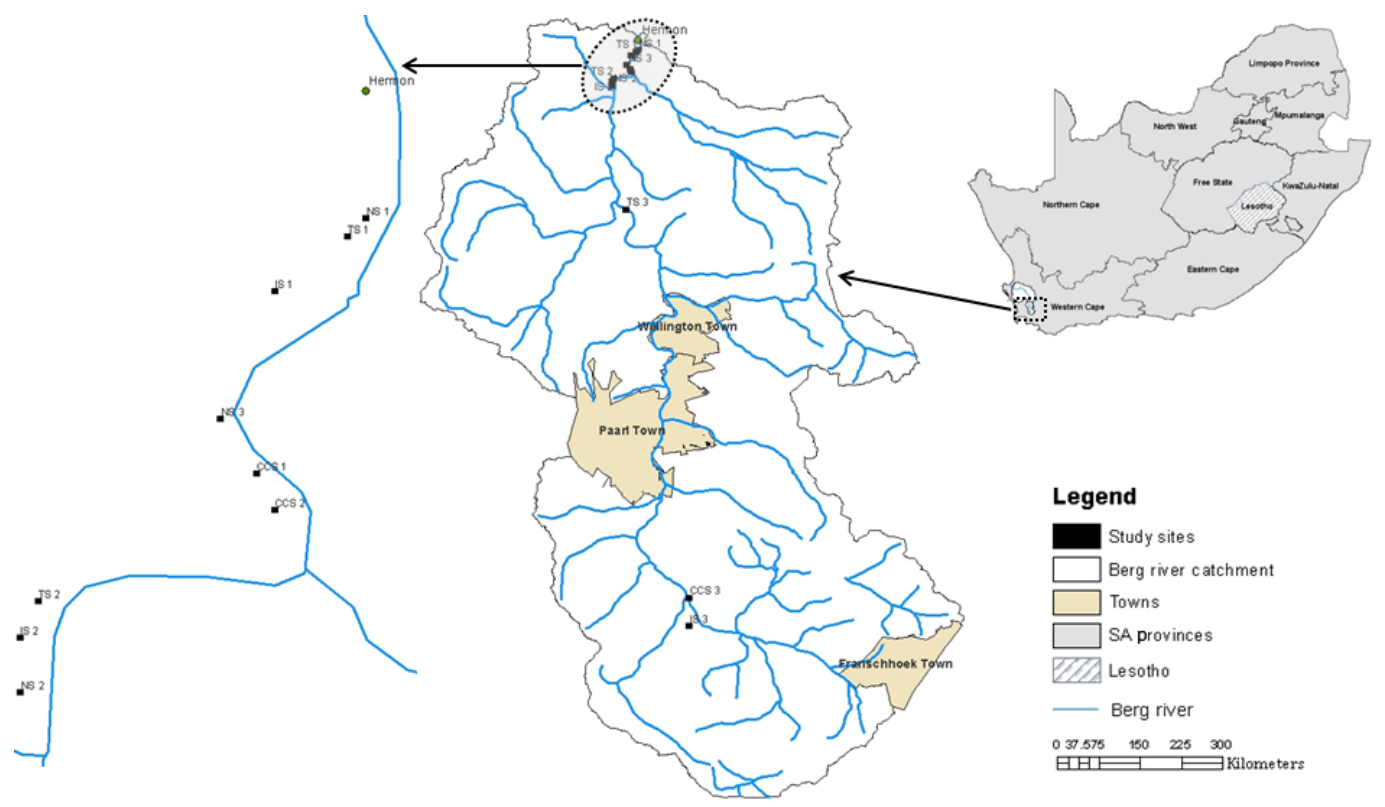

Fig. 1. Location of the study area and the four sites, namely invaded sites (IS), thinned sites (TS), completely cleared sites (CCS) and natural sites (NS), with each site replicated three times (e.g. IS 1, IS 2 and IS 3) in a restoration project at the Berg River in the Western Cape, South Africa. 
Table 1. Study area characteristics showing the four treatments, namely invaded sites (IS), thinned sites (TS), completely cleared sites (CCS) and natural sites (NS), each site replicated three times in a restoration project at the Berg River in the Western Cape, South Africa. Each site's UTM (Universal Transverse Mercator) coordinate location is shown. Mean values of soil carbon (\%) and soil pH were obtained from randomly selected soil samples collected during 2010. The soil type at all sites was sand.

\begin{tabular}{|c|c|c|c|c|}
\hline Restoration type & Site name & Coordinates & Soil carbon (\%) & Soil pH \\
\hline \multirow[t]{3}{*}{ Invaded sites } & IS 1 & $33^{\circ} 26^{\prime} 58.56^{\prime \prime} \mathrm{S}, 18^{\circ} 57^{\prime} 11.47^{\prime \prime} \mathrm{E}$ & 1.76 & 4.4 \\
\hline & 152 & $33^{\circ} 28^{\prime} 09.41^{\prime \prime} \mathrm{S}, 18^{\circ} 56^{\prime} 18.98^{\prime \prime} \mathrm{E}$ & 2.20 & 4.57 \\
\hline & 153 & $33^{\circ} 52^{\prime 2} 1.53^{\prime \prime} \mathrm{S}, 18^{\circ} 59^{\prime} 45.09^{\prime \prime} \mathrm{E}$ & 1.78 & 3.67 \\
\hline \multirow[t]{3}{*}{ Thinned Sites } & TS 1 & $33^{\circ} 26^{\prime} 49.05^{\prime \prime} \mathrm{S}, 18^{\circ} 57^{\prime} 23.63^{\prime \prime} \mathrm{E}$ & 2.36 & 4.93 \\
\hline & TS 2 & $33^{\circ} 28^{\prime} 00.56^{\prime \prime} \mathrm{S}, 18^{\circ} 56^{\prime} 23.98^{\prime \prime} \mathrm{E}$ & 0.91 & 4.8 \\
\hline & TS 3 & $33^{\circ} 33^{\prime} 50.58^{\prime \prime} \mathrm{S}, 18^{\circ} 56^{\prime} 56.28^{\prime \prime} \mathrm{E}$ & 1.19 & 4.67 \\
\hline \multirow[t]{3}{*}{ Completely Cleared sites } & CCS 1 & $33^{\circ} 27^{\prime} 35.89^{\prime \prime} \mathrm{S}, 18^{\circ} 57^{\prime} 07.35^{\prime \prime} \mathrm{E}$ & 1.06 & 4.37 \\
\hline & $\operatorname{ccs} 2$ & $33^{\circ} 27^{\prime} 43.60^{\prime \prime} \mathrm{S}, 18^{\circ} 57^{\prime} 12.05^{\prime \prime} \mathrm{E}$ & 2.59 & 4.5 \\
\hline & $\operatorname{ccs} 3$ & $33^{\circ} 51^{\prime} 07.37^{\prime \prime} \mathrm{S}, 18^{\circ} 59^{\prime} 46.33^{\prime \prime} \mathrm{E}$ & 1.74 & 3.66 \\
\hline \multirow[t]{3}{*}{ Natural Sites } & NS 1 & $33^{\circ} 26^{\prime} 46.83^{\prime \prime} \mathrm{S}, 18^{\circ} 57^{\prime} 27.72^{\prime \prime} \mathrm{E}$ & 1.30 & 4.93 \\
\hline & NS 2 & $33^{\circ} 28^{\prime} 18.48^{\prime \prime} \mathrm{S}, 18^{\circ} 56^{\prime \prime} 19.32^{\prime \prime} \mathrm{E}$ & 2.07 & 4.43 \\
\hline & NS 3 & $33^{\circ} 27^{\prime} 26.46^{\prime \prime} \mathrm{S}, 18^{\circ} 56^{\prime} 59.60^{\prime \prime} \mathrm{E}$ & 2.66 & 4.7 \\
\hline
\end{tabular}

\section{Experimental design and field sampling}

A detailed survey of the riparian vegetation was undertaken at all 12 sites. Plots measuring $10 \mathrm{~m} \times 10 \mathrm{~m}$ with a $5 \mathrm{~m}$ buffer zone (each plot replicated five times per site) were set up in the riparian zone. The study focused on the dry zone because the wet bank was very narrow and is prone to flooding during winter, thus making it less susceptible to riparian scrub establishment (Boucher 2002; Galatowitsch \& Richardson 2005).

Field data were collected between September and October (spring) 2010, during which time most herbaceous species should be apparent, and re-sampled in spring 2011 to verify results. Within each plot, total vegetation cover for all identified species of both indigenous and alien plants (crown cover for trees and shrubs and proportional cover for herbaceous and graminoids) was estimated (to the nearest $5 \%$ or to the nearest $1 \%$ when species occupied $<5 \%)$ as a percentage of the entire plot $\left(50 \mathrm{~m}^{2}\right)$. Vegetation composition (relative cover) was measured using estimated percentage cover for all individual plant species (indigenous and alien) present within the plot. Herbaceous and graminoid species richness was determined from counts of the total numbers of individual plant species (indigenous and alien) present in a $1-\mathrm{m}^{2}$ quadrat placed at the edge of the plot, while species richness of trees and shrubs was measured in $50-\mathrm{m}^{2}$ plots. Species were assigned to growth forms based on morphology and maximum height reached, as described in Goldblatt $\delta$ Manning (2000). The four broad growth form classes used in this study are trees, shrubs, forbs (herbaceous plants), geophytes (perennial plants that are propagated by buds on underground bulbs, tubers or corms) and graminoids including restioids (reed-like plants that belong to the Restionaceae or Cape Reed family, commonly found in the
Fynbos). Twelve random soil samples (one per site) were collected from the study sites and tested for soil carbon (\%) and soil pH (Table 1). Soil carbon was analysed using a modified Walkley Black method as described in Chan et al. (2001), while $\mathrm{pH}$ was measured with a pH meter following 1:5 soil:KCl ratio (Rhoades 1982).

All recognizable species were collected in the field for identification. Species were labelled as native or alien following the criteria of Pyšek et al. (2004) and using published floras, including Goldblatt \& Manning (2000), Henderson (2001) and Bromilow (2010). Species that could not be positively identified were collected and labelled with a unique specimen number and sent to a local herbarium for identification.

\section{Data analysis}

For each treatment, total cover, species richness and diversity of both native and alien speces were calculated for each plot. Simpson's index of diversity (1-D), ShannonWiener diversity index $\left(\mathrm{H}^{\prime}\right)$ and Evenness index $(\mathrm{J})$ using Pielou's 'J' (Zar 1996) were used to examine the effect of treatments on species diversity. The effects of the different restoration treatments on the above-mentioned vegetation variables and indices were compared using one-way ANOVA in Statistica v 10 (Statsoft Inc 2010; http://www. statsoft.com) after proof of normality using Shapiro-Wilk and Kolmogorov-Smirnov tests and proof of homogeneity of variances using the Levene test. Data that failed the equal variance test were log-transformed. Where ANOVAs were significant, Tukey's HSD unequal $n$ test was used to determine differences between individual treatments at $P<0.05$.

To test whether there is a difference in the composition (using relative cover) between treatments, we first categorized 
our species into the above-mentioned growth forms and calculated relative cover for each plot, i.e. the cover of each study species relative to the sum of cover for all species per plot (in their respective growth form categories). We then used the mean relative cover to compare species composition and assemblage in the different treatments. Comparisons were between NS and all other treatments, namely CCS, TS and IS, as well as between CCS and TS.

\section{Results}

\section{Effects of different treatments on vegetation cover}

A total of 83 plant species were recorded for all treatments, of which 24 were trees and shrubs (eight alien and 16 native taxa), 41 were herbaceous (33 alien, eight native), ten were graminoids (eight alien, two native) and eight were restioids and geophytes (five alien, three native). With the exception of NS, most of the identified plant species on all treatments were alien species (Fig. 2, Table 2).

There were significant differences in native vegetation cover among treatments $(P<0.001$; Table 3$)$. A Tukey test indicated that vegetation cover of all natives was lowest in IS compared to the other treatments (NS, CCS and TS). The reduced native vegetation cover in IS compared to the other treatments (NS, CCS and TS) was observed for all measured growth forms (Table 3 ). In contrast, vegetation cover of all alien species was significantly lower in NS compared to IS $(P<0.001)$. However, a Tukey test on vegetation cover of all alien species indicated that there was no significant difference between IS and CCS or TS. Similarly, vegetation cover of alien trees and shrubs was significantly lower in NS compared to IS $(P<0.001)$. Significantly higher alien herb cover $(P<0.001)$ and alien graminoid cover $(P<0.001)$ was observed in CCS

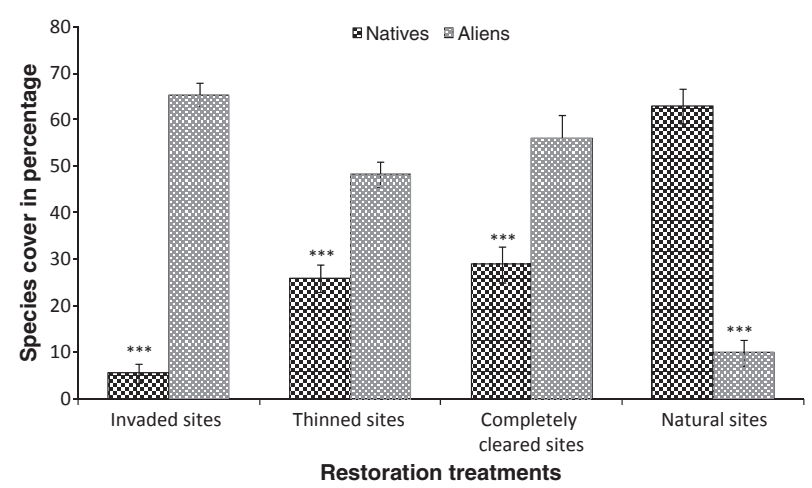

Fig. 2. Cover of alien and native plant species $4 \mathrm{yr}$ after administering four treatments (invaded sites (IS), thinned sites (TS), completely cleared sites (CCS) and natural sites (NS)) along the Berg River in the Western Cape, South Africa. Bars are mean $\pm S D$ and results of one-way ANOVAs are shown $(* P<0.05, * * P<0.01, * * * P<0.001)$.
Table 2. The 36 most frequently occurring species identified from the four different treatments, named as invaded sites (IS), thinned sites (TS), completely cleared sites (CCS) and natural sites (NS), in a restoration project at the Berg River in the Western Cape, South Africa. Species are grouped into four broad growth form classes: trees, shrubs, forbs (herbaceous plants) and graminoids.

\begin{tabular}{lllll}
\hline Species name & Invaded & Thinned & Completely & Natural \\
& sites & sites & cleared & sites \\
& & & sites &
\end{tabular}

\section{Trees}

\begin{tabular}{|c|c|c|c|c|}
\hline Kiggelaria africana & ++++ & ++++ & +++ & +++++ \\
\hline $\begin{array}{l}\text { Searsia angustifolia (syn. } \\
\text { Rhus angustifolia) }\end{array}$ & + & ++ & ++ & ++ \\
\hline Podocarpus elongatus & - & - & - & +++ \\
\hline $\begin{array}{l}\text { Olea europaea subsp. } \\
\text { africana }\end{array}$ & + & ++ & + & +++ \\
\hline Halleria lucida & - & - & + & - \\
\hline Maytenus oleoides & - & + & + & +++ \\
\hline Acacia karroo & - & - & - & ++ \\
\hline *Eucalyptus camaldulensis & ++++ & ++++ & ++ & + \\
\hline${ }^{\star}$ Acacia mearnsii & +++ & ++++ & ++ & - \\
\hline${ }^{\star}$ Acacia longifolia & + & ++ & - & - \\
\hline \multicolumn{5}{|l|}{ Shrubs and Sub-shrubs } \\
\hline Diospyros glabra & - & ++ & +++ & ++ \\
\hline Stoebe plumosa & - & + & + & - \\
\hline${ }^{\star}$ Rubus cuneifolius & + & + & + & + \\
\hline *Sesbania punicea & - & - & + & - \\
\hline *Solanum mauritianum & ++ & + & + & + \\
\hline \multicolumn{5}{|l|}{ Herbs/Forbs } \\
\hline Zantedeschia aethiopica & + & + & +++ & +++++ \\
\hline Oxalis purpurea & + & + & + & +++ \\
\hline Senecio polyanthemoides & + & +++ & + & + \\
\hline Juncus capensis & - & + & + & - \\
\hline Asparagus africanus & - & - & + & + \\
\hline *Verbena bonariensis & - & ++ & + & + \\
\hline *Solanum nigrum & - & +++ & ++ & ++ \\
\hline *Taraxacum officinale & + & ++ & +++ & + \\
\hline *Picris echioides & - & + & +++ & + \\
\hline *Rumex crispus & - & + & +++ & - \\
\hline *Stellaria media & + & ++ & + & - \\
\hline * Lactuca serriola & - & ++ & ++ & - \\
\hline *Xanthium strumarium & - & + & ++ & - \\
\hline *Sonchus oleraceus & + & + & + & - \\
\hline *Fumaria muralis & - & + & ++ & + \\
\hline \multicolumn{5}{|l|}{ Graminoids } \\
\hline Cynodon dactylon & + & + & + & + \\
\hline Ehrharta calycina & - & + & + & + \\
\hline *Avena fatua & + & ++ & ++++ & + \\
\hline *Briza maxima & + & - & ++ & ++ \\
\hline *Bromus catharticus & + & +++ & ++++ & + \\
\hline *Lolium multiflorum & + & ++ & + & - \\
\hline
\end{tabular}

$(+)$ Indicates that the species was present at the site, and is based on calculated species occupancy frequencies categorized as + (1-20\%), ++ (21$40 \%),+++(41-60 \%),++++(61-80 \%)$ and $+++++(81-100 \%)$, with $(-)$ indicating that the species was not present. *non-indigenous species.

compared to the other three treatments (NS, IS and TS). With regard to cover of geophytes and restioids, there were no significant differences among treatments, this 
Table 3. Effects of the four different treatments [named as invaded sites (IS), thinned sites (TS), completely cleared sites (CCS) and natural sites (NS)] on vegetation cover in a restoration project at the Berg River in the Western Cape, South Africa. Vegetation cover is categorized as native or alien and into broad growth form classes.

\begin{tabular}{|c|c|c|c|c|c|}
\hline & Invaded sites & Thinned sites & Completely cleared sites & Natural sites & ANOVA $=F(3 ; 61)$ \\
\hline \multicolumn{6}{|l|}{ Indigenous vegetation (\%) } \\
\hline Cover of all natives & $5.67 \pm 3.36^{\mathrm{a}}$ & $26.00 \pm 2.91^{b}$ & $29.00 \pm 3.36^{b}$ & $63.00 \pm 3.36^{c}$ & $50.15^{\star * \star}$ \\
\hline Crown cover of native trees and shrubs & $5.67 \pm 3.49^{\mathrm{a}}$ & $25.75 \pm 3.03^{b}$ & $24.33 \pm 3.49^{b}$ & $63.00 \pm 3.49^{c}$ & $47.39 * * \star$ \\
\hline Proportional cover of native herbs & $0.20 \pm 2.67^{\mathrm{a}}$ & $5.05 \pm 2.31^{\mathrm{ab}}$ & $12.80 \pm 2.67^{b c}$ & $21.33 \pm 2.67^{c}$ & 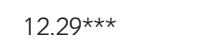 \\
\hline Proportional cover of native graminoids & $0.13 \pm 1.60^{\mathrm{a}}$ & $5.60 \pm 1.38^{\mathrm{ab}}$ & $6.33 \pm 1.60^{b}$ & $1.67 \pm 1.60^{\mathrm{ab}}$ & $5.70 * *$ \\
\hline \multicolumn{6}{|l|}{ Alien vegetation $(\%)$} \\
\hline Cover of all aliens & $65.33 \pm 3.51^{c}$ & $48.24 \pm 3.04^{b}$ & $56.00 \pm 3.51^{b c}$ & $10.00 \pm 3.51^{\mathrm{a}}$ & $47.88^{\star \star \star}$ \\
\hline Crown cover of alien trees and shrubs & $65.33 \pm 2.44^{c}$ & $48.75 \pm 2.12^{\mathrm{b}}$ & $4.80 \pm 2.44^{\mathrm{a}}$ & $5.00 \pm 2.44^{\mathrm{a}}$ & $165.05^{\star \star \star}$ \\
\hline Proportional cover of alien Herb & $0.73 \pm 3.18^{\mathrm{a}}$ & $13.50 \pm 2.18^{\mathrm{b}}$ & $37.53 \pm 3.18^{c}$ & $6.00 \pm 3.18^{\mathrm{ab}}$ & $26.24 \star \star \star *$ \\
\hline Proportional cover of alien graminoids & $1.00 \pm 3.89^{\mathrm{a}}$ & $11.00 \pm 3.37^{\mathrm{a}}$ & $41.33 \pm 3.89^{b}$ & $9.67 \pm 3.89^{\mathrm{a}}$ & 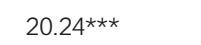 \\
\hline \multicolumn{6}{|l|}{ Other growth forms (\%) } \\
\hline Proportional cover of geophytes & $0.00 \pm 0.00^{\mathrm{a}}$ & $0.70 \pm 0.66^{\mathrm{a}}$ & $2.40 \pm 0.76^{a}$ & $0.00 \pm 0.00^{\mathrm{a}}$ & $2.33^{\text {n.s. }}$ \\
\hline Proportional cover of restioids & $0.00 \pm 0.00^{\mathrm{a}}$ & $0.40 \pm 0.15^{a}$ & $0.07 \pm 0.17^{\mathrm{a}}$ & $0.00 \pm 0.00^{\mathrm{a}}$ & $2.23^{\text {n.s. }}$ \\
\hline
\end{tabular}

Data are mean $\pm S D$ and results of one-way ANOVAs are shown $(* P<0.05, * * P<0.01, * * * P<0.001)$. Columns with different letter superscripts are significantly different.

was possibly caused by the lack of these growth forms in IS and NS (Table 3).

\section{Effects of different treatments on species diversity and abundance}

Species richness of alien and native species combined was significantly higher in both CCS and TS compared to IS and NS $(P<0.001 ;$ Table 4$)$. This difference was more marked for alien species, whose richness was higher in CCS and TS compared to IS and NS $(P<0.001)$ (Table 4, Fig. 3). There were significant differences in native species richness among treatments $(P<0.001)$, with native species richness being higher in all other treatments (NS, CCS and TS) compared to IS (Table 4, Fig. 3).
Diversity indices differed significantly between treatments, using the Simpson index of diversity and the Shannon-Wiener indices. TS recorded the highest diversity as compared to IS $(P<0.001)$. However, the Tukey test (on the two above-mentioned indices) indicated that there were no significant differences between NS and CCS, as well as between TS and CCS $(P>0.05)$. Thinned sites (TS) showed higher evenness compared to CCS $(P<0.01)$, however there were no significant differences between IS and NS $(P>0.05$; Table 4$)$.

\section{Comparisons of species composition and assemblages in the different treatments}

Mean relative cover of trees and shrubs (both native and alien) and native herbaceous species was higher in NS

Table 4. Effects of the four different treatments [invaded (IS), thinned (TS), completely cleared (CCS) and natural (NS)] on plant diversity and abundance indices in a restoration project at the Berg River in the Western Cape, South Africa. Species richness is categorized as native or alien and into broad growth form classes.

\begin{tabular}{|c|c|c|c|c|c|}
\hline & Invaded sites & Thinned sites & Completely cleared sites & Natural sites & ANOVA $=F(3 ; 61)$ \\
\hline Species richness & $4.80 \pm 0.58^{\mathrm{a}}$ & $12.70 \pm 0.77^{b}$ & $11.13 \pm 0.94^{b}$ & $6.87 \pm 0.49^{\mathrm{a}}$ & $25.63^{\star \star \star}$ \\
\hline Simpsons index of diversity & $0.65 \pm 0.05^{\mathrm{a}}$ & $0.88 \pm 0.01^{c}$ & $0.78 \pm 0.05^{b c}$ & $0.74 \pm 0.02^{\mathrm{ab}}$ & $5.32^{\star \star}$ \\
\hline Shannon-Wiener & $1.21 \pm 0.12^{\mathrm{a}}$ & $2.28 \pm 0.07^{c}$ & $1.91 \pm 0.14^{\mathrm{bc}}$ & $1.56 \pm 0.08^{\mathrm{ab}}$ & $21.45^{\star \star \star}$ \\
\hline Evenness index & $0.83 \pm 0.03^{\mathrm{ab}}$ & $0.91 \pm 0.01^{b}$ & $0.79 \pm 0.04^{\mathrm{a}}$ & $0.83 \pm 0.02^{\mathrm{ab}}$ & $2.71 *$ \\
\hline \multicolumn{6}{|c|}{ Species richness per invasion status } \\
\hline Richness of natives & $1.13 \pm 0.24^{\mathrm{a}}$ & $3.85 \pm 0.35^{b}$ & $3.53 \pm 0.42^{b}$ & $4.47 \pm 0.32^{b}$ & $16.87^{\star \star \star}$ \\
\hline Richness of aliens & $3.20 \pm 0.35^{\mathrm{a}}$ & $7.00 \pm 0.52^{b}$ & $6.13 \pm 0.53^{b}$ & $1.87 \pm 0.39^{\mathrm{a}}$ & $26.64^{\star \star \star}$ \\
\hline \multicolumn{6}{|l|}{ Species richness per growth form } \\
\hline Richness of trees and shrubs & $3.20 \pm 0.33^{\mathrm{a}}$ & $4.65 \pm 0.21^{b}$ & $3.67 \pm 0.35^{\mathrm{ab}}$ & $3.27 \pm 0.28^{\mathrm{a}}$ & $6.09^{\star \star \star *}$ \\
\hline Richness of herbs & $1.07 \pm 0.36^{\mathrm{a}}$ & $5.10 \pm 0.59^{c}$ & $4.67 \pm 0.58^{\mathrm{bc}}$ & $2.93 \pm 0.34^{\mathrm{ab}}$ & $13.05^{\star \star \star}$ \\
\hline Richness of graminoids & $0.53 \pm 0.24^{\mathrm{a}}$ & $2.30 \pm 0.22^{b}$ & $2.47 \pm 0.34^{b}$ & $0.73 \pm 0.18^{\mathrm{a}}$ & $18.42^{\star \star \star}$ \\
\hline Richness of geophytes & $0.00 \pm 0.00^{\mathrm{a}}$ & $0.30 \pm 0.15^{a}$ & $0.47 \pm 0.24^{\mathrm{a}}$ & $0.00 \pm 0.00^{\mathrm{a}}$ & $1.35^{\text {n.s. }}$ \\
\hline Richness of restioids & $0.00 \pm 0.00^{\mathrm{a}}$ & $0.35 \pm 0.15^{b}$ & $0.07 \pm 0.07^{a}$ & $0.00 \pm 0.00^{\mathrm{a}}$ & $3.31^{\star}$ \\
\hline
\end{tabular}

Data are mean $\pm S D$ and results of one-way ANOVAs are shown $(* P<0.05, * * P<0.01, * * * P<0.001)$. Columns with different letter superscripts are significantly different. 


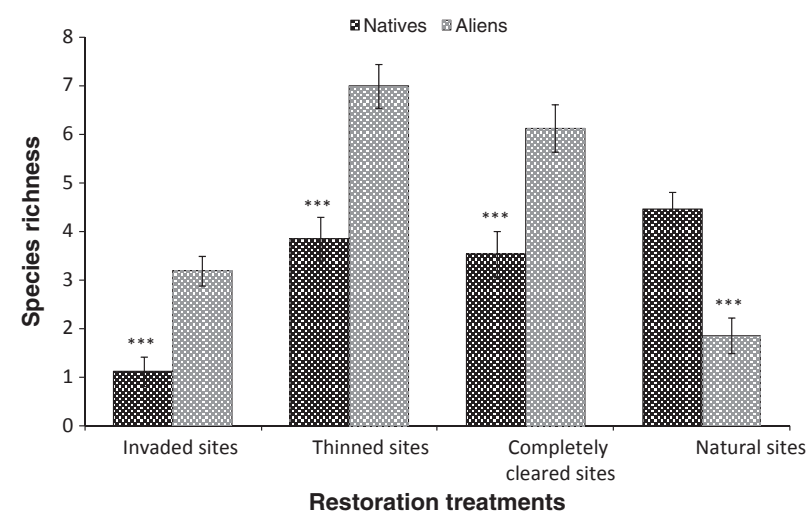

Fig. 3. Species richness of alien and native plant species $4 \mathrm{yr}$ after administering four treatments [invaded sites (IS), thinned sites (TS), completely cleared sites (CCS) and natural sites (NS)] along the Berg River in the Western Cape, South Africa. Bars are mean $\pm \mathrm{SD}$ and results of oneway ANOVAs are shown $(* P<0.05, * * P<0.01, * * * P<0.001)$.

compared to CCS, although there was no significant difference in alien trees and shrubs $(P>0.05)$. In contrast, mean relative cover of graminoids (both native and alien) and alien herbaceous species was higher in CCS compared to NS (Fig. 4a). Comparison between NS and TS shows that mean relative cover of all alien species was significantly higher in TS compared to NS $(P<0.05)$, although there was no significant difference in alien graminoids $(P>0.05)$. Mean relative cover of native trees and shrubs and native herbaceous species was significantly higher in NS compared to TS $(P<0.01$; Fig. $4 \mathrm{~b})$.

Comparison of NS and IS showed that mean relative cover of all other growth forms was significantly higher in NS compared to IS $(P<0.01)$, except for alien trees and shrubs, which was significantly higher in IS compared to NS $(P<0.001 ;$ Fig. 4c). Comparisons between the two clearing treatments of CCS and TS indicate that native trees and shrubs were common in both treatments. There was no significant difference in mean relative cover of native trees and shrubs and native graminoids between the two clearing treatments of CCS and TS $(P>0.05)$. Mean relative cover of alien herbaceous and graminoid species was significantly higher in CCS compared to TS $(P<0.001$; Fig. 4d).
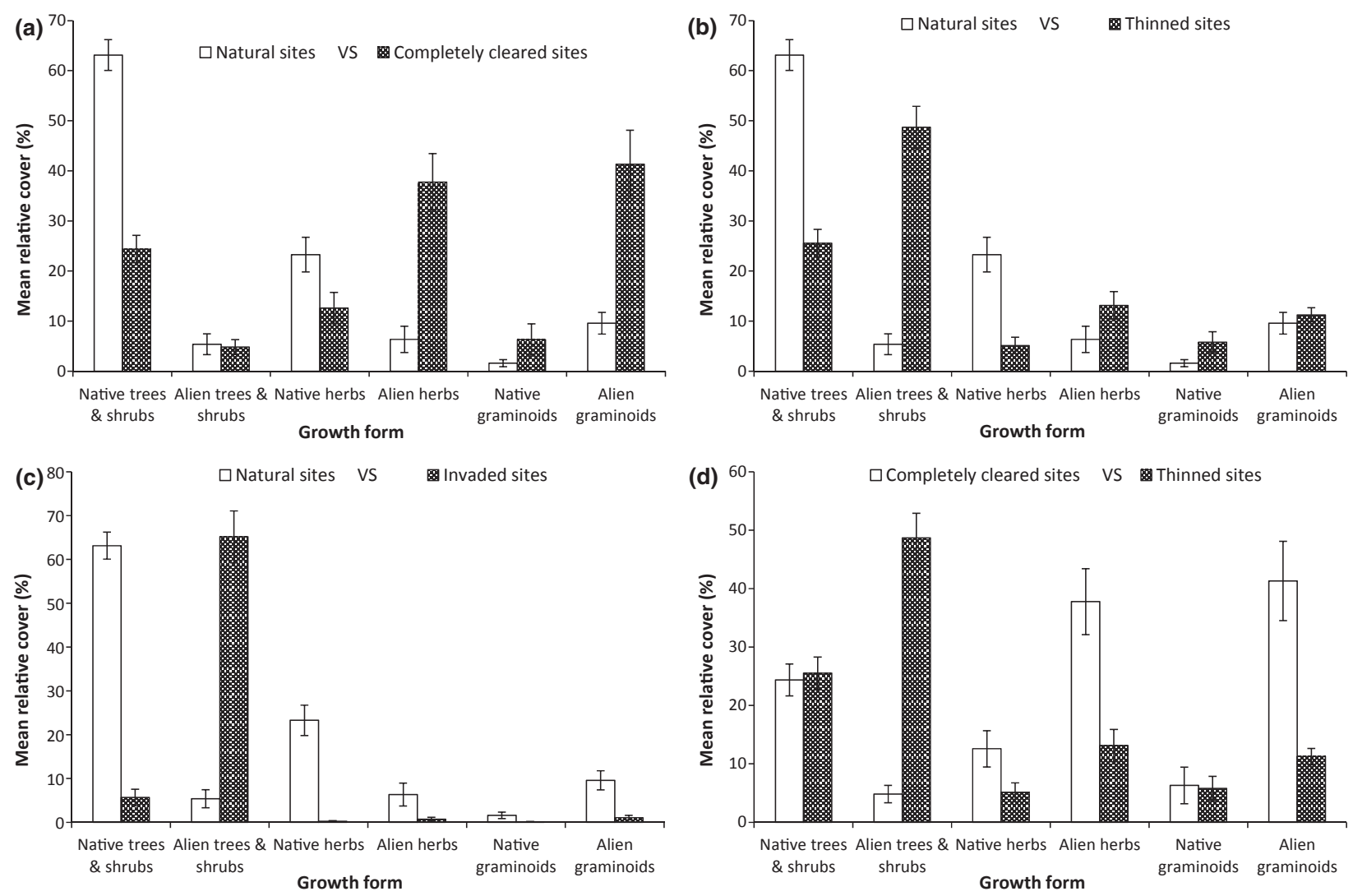

Fig. 4. Relative cover of native and alien species (grouped in different growth forms) $4 \mathrm{yr}$ after administering four treatments [invaded (IS), thinned (TS), completely cleared (CCS) and natural sites (NS)] along the Berg River in the Western Cape, South Africa. Bars are mean \pm SD and results of one-way ANOVAs are shown. Comparisons are between: (a) natural vs completely cleared sites, (b) natural vs thinned sites, (c) natural vs invaded sites, (d) completely cleared and thinned sites. 


\section{Discussion}

Impacts of Eucalyptus camaldulensis on resident plants

Results of this study suggest that native vegetation cover, richness and abundance along riparian zones of the Berg River are all negatively affected by E. camaldulensis invasion. This result supports the findings of several other studies in the Western Cape (Richardson et al. 2000a; Richardson \& Van Wilgen 2004; Holmes et al. 2005) that have shown that invasive alien plants, especially taxa of Acacia, Eucalyptus and Pinus, alter the abundance and composition of native plant species. Furthermore E. camaldulensis invasion along the Berg River has the capacity to change ecosystem structure and functioning (Forsyth et al. 2004).

Mechanisms that promote the observed reduced native species richness and abundance in E. camaldulensis invaded sites are still poorly understood. In some cases, the ability of Eucalyptus species to outcompete natives for water and nutrient resources (Holmes et al. 2005; Richardson et al. 2007), as well as reduced light penetration due to Eucalyptus canopy cover (Galatowitsch \& Richardson 2005) and allelopathy (Sasikumar et al. 2002) have been used to explain lack of native species in Eucalyptus-invaded sites. Additionally, it has been reported that alien invasion can cause declines in native species soil-stored seed banks (Fourie 2008; Vosse et al. 2008).

\section{Recovery of native species after removal of alien species}

Recovery after complete clearing

Recovery of native vegetation in completely cleared sites (CCS) $4 \mathrm{yr}$ after initial clearing showed considerable increases in richness, cover and abundance of native vegetation compared to IS. Previous results on recovery of native vegetation after complete alien clearing in South Africa have yielded mixed results. Reinecke et al. (2008) found that, 4 yr after pine clearing, native vegetation was successfully recovering, with no need for active restoration. Conversely, Galatowitsch \& Richardson (2005) and Blanchard \& Holmes (2008) reported significantly low indigenous tree regeneration after removal of Acacia longifolia and Acacia mearnsii, and suggested that intervention was required to stimulate recovery.

The recovery of native species following complete alien clearing is mainly influenced by the availability of native soil-stored seed banks and the supply of native propagules from the surrounding landscape (Galatowitsch \& Richardson 2005; Holmes et al. 2005). Studies on riparian soilstored seed banks have shown that the extent of alien invasion and soil moisture regimes (wet and dry bank zones) influences the seed bank species assemblage (Fourie
2008; Vosse et al. 2008). However, the same studies concluded that native species soil seed banks in riparian systems of the Western Cape appear to be adequate to enable a functional cover of indigenous vegetation to re-establish after alien clearing (Fourie 2008; Vosse et al. 2008). No studies in the Fynbos have examined how long soil-stored seed banks remain viable following invasion, however, it is known that native soil-stored seed banks become depleted with increasing invasion intensity (Holmes et al. 2005; Vosse et al. 2008). Besides the native soil-stored seed bank, supply of native seeds and propagules from surrounding landscapes is important for recovery (Galatowitsch $\delta$ Richardson 2005), because many species are not represented in the seed bank. However, poor recruitment of riparian species on arrival at cleared sites may also relate to unsuitable germination or establishment conditions (Holmes et al. 2005).

Native species recovery and colonization on completely cleared sites can also be accelerated by the presence of remnant indigenous plants, through their effects on seed dispersal (Holmes \& Richardson 1999). Isolated remnant native species play an important role in site recovery by serving both as recovery perches and food resources for seed dispersers (Guariguata \& Ostertag 2001). Heelemann et al. (2012) reported that frugivorous birds of the Cape Lowlands of South Africa significantly increased seed dispersal at artificial perch sites, although seed establishment was affected by seed predation and unfavourable germination conditions.

\section{Recovery after thinning}

Our results on thinning revealed considerable increases in richness, cover and abundance of native vegetation compared to IS, although thinning sites (TS) were similar to CCS. Previous studies on vegetation response to thinning have yielded varying results ranging from increases in total plant species abundance (Busse et al. 2000; Moore et al. 2006) to no response or to decreases in plant species abundance (Nelson et al. 2008). Although not tested in our study, we assume that the presence of native species in our thinned sites may have been caused by increases in resource availability. Studies have shown that increased light, water and nutrient resources are the main factors stimulating increased species abundance following thinning (Gundale et al. 2005; Moore et al. 2006).

Observations from our thinned sites suggest that recovery of native species on these sites is profoundly dependent on the availability of understorey shade-tolerant native tree and shrub species. Van Wyk et al. (1995) showed that native vegetation was restored following thinning of plantation stands. Geldenhuys (1997) subsequently suggested that the development of understorey shade-tolerant native 
species under both plantations and invaded riparian systems could successfully facilitate recovery of native species. However, this should be accompanied with careful planning and thinning implementation to curb the re-establishment of alien invaders. In this regard, more research is needed to understand levels of thinning that yield the best native species recovery.

\section{Secondary alien herbaceous and graminoids invasion}

A notable feature of the vegetation at both complete removal and thinned sites was the exceptionally high cover and richness of alien herbaceous and graminoid species. Proliferation of these life forms following the removal of alien species has been documented in terrestrial fynbos communities (Richardson et al. 2000a; Galatowitsch \& Richardson 2005) as well as in savanna and grassland communities of South Africa, where new dominant invasive species have replaced the cleared species (Beater et al. 2008).

Dominance of alien herbaceous and graminoid species has been attributed to nutrient-enriched soils resulting from nitrogen fixation by alien trees (Richardson et al. 2000b), this being more common with Acacia spp. (Yelenik et al. 2004). Studies have shown that soils beneath Eucalyptus stands have increased soil fertility, organic carbon content, total and available nutrients, mainly due to abundant decayed litter produced by eucalypts (Balamurungan et al. 2000). However, the decay/decline rate of soil nutrients after Eucalyptus removal, more likely to be caused by the non-use of nutrients by Eucalyptus as well as the lack of litter supply, is still unknown. Studies on removal of other alien species (e.g. A. longifolia) have shown that it takes several years before soil nutrients return to pre-invasion levels (Marchante et al. 2011). Although not tested in this study, we suspect that 4-5 yr after both complete Eucalyptus removal and thinning, the nutrient levels were still high, thus stimulating the growth of alien herbaceous and graminoid species. The proliferation of these alien herbaceous and graminoid species could have negative effects on native vegetation recovery.

\section{Management implications}

The presence of native species in both CCS and TS treatments indicates that native ecosystem functioning was still resilient enough for autogenic recovery to occur after removal of the invasive species. We suspect that both biotic and abiotic thresholds at these two sites were not sufficiently severely depleted to warrant structural and functional recovery intervention. Therefore, even after several decades of Eucalyptus invasion, a positive trajectory towards recovery of ecosystem structure and composition after clearing or thinning can be expected with time. However, the proliferation of alien herbaceous and graminoid species has the potential to slow recovery. Nonetheless, we suggest that remnant native species (which are crucial for enhancing recovery) at both CCS and TS should be protected from accidental clearing and herbicide spraying, which might occur during follow-up operations.

Adopting thinning as a clearing and restoration strategy in riparian zones should be done with caution. From a sustainability perspective, thinned Eucalyptus trees can be sold as timber to help fund the restoration efforts. However, developing roads to transport both equipment and harvested timber can result in further invasion of alien plants (Bailey et al. 1998). Also, soil disturbances associated with thinning (also a problem in completely cleared sites) can enhance establishment of ruderal alien species (Bailey et al. 1998). Floating of cut trees along the river to the nearest accessible town as a means of avoiding soil disturbance and alien invasion has been suggested (Schweithem et al. 1992); however, this is not a viable option with the seasonally low-flow rivers typical for this region.

Given the observed presence of native tree and shrub species on our thinned sites, we suggest that thinning 40$50 \%$ of alien tree cover, targeting large Eucalyptus trees, has the potential to stimulate native recovery. Targeting large trees could provide financial benefits to landowners from the sale of timber, which could potentially be used to finance overall restoration efforts. Where native shade-tolerant understorey vegetation is present the recovery after thinning will likely follow the four-stage succession process suggested in Geldenhuys (2008) (Fig. 5). The first stage is associated with a mixed stand of both Eucalyptus and understorey native vegetation. The first thinning (stage 2) should target large and mature Eucalyptus stands. This will provide light and other resources for native understorey vegetation. As native understorey vegetation begins to grow at stage 2 , dispersal of the seeds and introduction of other native species from nearby natural forests by birds will result in establishment of native understorey vegetation. At stage 3 we suggest further thinning of Eucalyptus, especially those individuals that are out-growing the establishing native understorey vegetation. This stage is critical, since a complete removal of Eucalyptus may allow alien herbs and grasses and other opportunistic tree invaders to invade the system. Thinning at this stage should also focus on creating more space in the understorey native vegetation, thus facilitating the development of a native forest community with desired functional attributes. In the final stage (stage 4) all Eucalyptus individuals should be removed. According to Geldenhuys (2008) this is the advanced development stage when the community is progressing towards a continuous self-sustaining forest assemblage. Although based on ideas expressed in Geldenhuys 


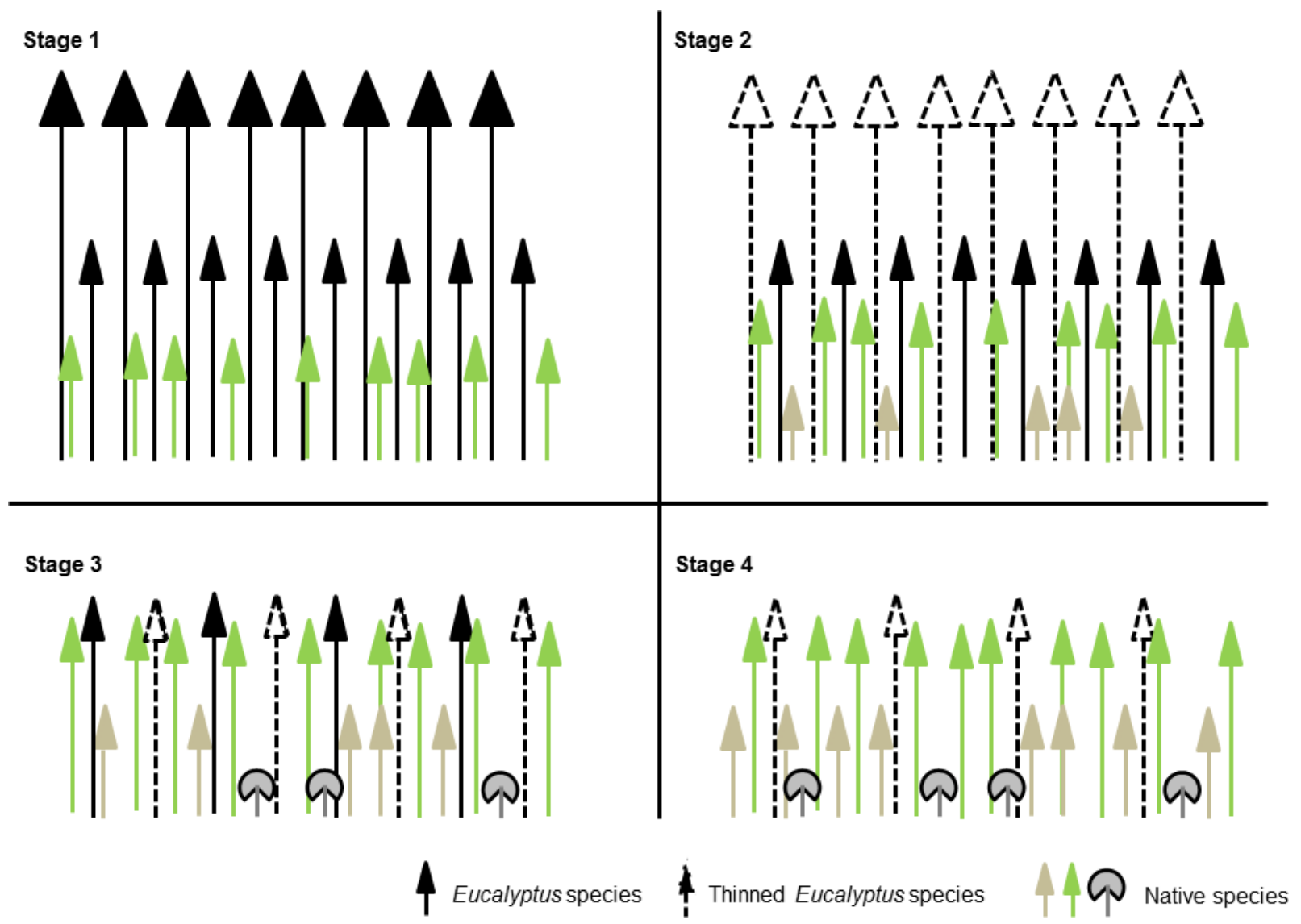

Fig. 5. Generalized stages of native vegetation recovery after thinning of alien trees. Scheme adapted from Van Wyk et al. (1995) and Geldenhuys (2008). See section on "Management implications" in the Discussion for elucidation of the stages.

(2008) and Van Wyk et al. (1995), our suggested approach advocates continuous thinning at stages 3 and 4, contrary to natural mortality of the invaders at the same stages, as suggested by these authors. We believe that the abovementioned interventions at stages 3 and 4 are required to speed up recovery and to allow for correctional manipulations at these stages.

We conclude that both complete clearing and thinning facilitate the recovery of native species in riparian systems invaded by invasive Eucalyptus species. The fact that native species re-established without active restoration intervention suggests that the native ecosystem was still resilient enough for autogenic recovery.

\section{Acknowledgements}

This work was funded by the DST-NRF Centre of Excellence for Invasion Biology (C.I.B) and the Working for Water Programme through their collaborative project on 'Research for Integrated Management of Invasive Alien Species'. SR also thanks the Oppenheimer Memorial Trust for additional funding (OMT Ref. 19351/01 and 19351/ 02). DMR acknowledges funding from the National Research Foundation. We thank the farmers in the upper Berg River catchment for permission to work on their land. We thank Manfred Paulsen (WfW implementation manager), Suzaan Kritzinger-Klopper (Senior Technical Officer at the C.I.B) for technical support and assistance in liaising with landowners, and Farai Tererai for general assistance.

\section{References}

Bailey, J.D., Mayrsohn, C., Doescher, P.S., St. Pierre, E. \& Tappeiner, J.C. 1998. Understory vegetation in old and young Douglas-fir forests of western Oregon. Forest Ecology and Management 112: 289-302.

Balamurungan, J., Kumaraswamy, K. \& Rajarajan, A. 2000. Effect of Eucalyptus citriodora on the physical and chemical properties of soils. Journal of the Indian Society of Soil Science 48: 491-495.

Beater, M.M.T., Garner, R.D. \& Witkowski, E.T.F. 2008. Impacts of clearing invasive alien plants from 1995 to 2005 on vege- 
tation structure, invasion intensity and ground cover in a temperate to subtropical riparian ecosystem. South African Journal of Botany 74: 495-507.

Bernhard-Reversat, F. 1999. The leaching of Eucalyptus hybrids and Acacia auriculiformis leaf litter: laboratory experiments on early decomposition and ecological implications in Congolese tree plantations. Applied Soil Ecology 12: 251-261.

Blanchard, R. \& Holmes, P.M. 2008. Riparian vegetation recovery after invasive alien tree clearance in the Fynbos biome. South African Journal of Botany 74: 421-431.

Boucher, C. 2002. Flows as determinants of riparian vegetation zonation patterns in selected southern African rivers. Proceeding of the International Conference on Environmental Flows for River Systems, incorporating the 4th International Ecohydraulics Symposium: An international working conference on assessment and implementation, 3-8 March 2002,, Cape Town, ZA.

Bromilow, C. 2010. Problem plants and alien weeds of South Africa. Briza Publications, Pretoria, ZA.

Busse, M.D., Simon, S.A. \& Riegel, G.M. 2000. Tree-growth and understory response to low-severity prescribed burning in thinned ponderosa pine forests of central Oregon. Forest Science 46: 258-268.

Chan, K.Y., Bowman, A. \& Oates, A. 2001. Oxidizible organic carbon fractions and soil quality changes in an Oxic Paleustalf under different pasture leys. Soil Science Society of America 166: 61-67.

De Villiers, S. 2007. The deteriorating nutrient status of the Berg River, South Africa. Water SA 33: 1-6.

Dye, P.J. \& Poulter, A.G. 1995. A field demonstration of the effect on stream flow of clearing invasive pine and wattle trees from a riparian zone. South African Forestry Journal 173: 27-30.

Esler, K.J., Holmes, P.M., Richardson, D.M. \& Witkowski, E.T.F. 2008. Riparian vegetation management in landscapes invaded by alien plants: insights from South Africa. South African Journal of Botany 74: 401-552.

Forsyth, G.G., Richardson, D.M., Brown, P.J. \& Van Wilgen, B.W. 2004. A rapid assessment of the invasive status of Eucalyptus species in two South African provinces. South African Journal of Science 100: 75-77.

Fourie, S. 2008. Composition of the soil seed bank in alieninvaded grassy Fynbos: potential for recovery after clearing. South African Journal of Botany 74: 445-453.

Gaertner, M., Holmes, P.M. \& Richardson, D.M. 2012. Biological invasions, resilience and restoration. In: van Andel, J. \& Aronson, J. (eds.) Restoration ecology: the new frontier, second edition, pp. 265-280. Blackwell, Oxford, UK.

Galatowitsch, S. \& Richardson, D.M. 2005. Riparian scrub recovery after clearing of invasive alien trees in headwater streams of the Western Cape, South Africa. Biological Conservation 122: 509-521.

Geldenhuys, C.J. 1997. Native forest regeneration in pine and eucalypt plantations in Northern Province, South Africa. Forestry Ecology and Management 99: 101-115.
Geldenhuys, C.J. 2008. Practical guidelines for the rehabilitation of forest-related streambank vegetation with removal of invader plant stands along the Berg River, Western Cape. Working for Water Report (FW - 02/08), ZA.

Goldblatt, P. \& Manning, J. 2000. Cape plants. A conspectus of the Cape Flora of South Africa. Strelitzia 9, National Botanical Institute, Pretoria, ZA.

Guariguata, M.R. \& Ostertag, R. 2001. Neotropical secondary forest succession: changes in structural and functional characteristics. Forest Ecology and Management 148: 185-206.

Gundale, M.J., DeLuca, T.H., Fiedler, C.E., Ramsey, P.W., Harrington, M.G. \& Gannon, J.E. 2005. Restoration treatments in a Montana ponderosa pine forest: effects of soil physical, chemical, and biological properties. Forest Ecology and Management 213: 25-38.

Heelemann, S., Krug, C.B., Esler, K.J., Reisch, C. \& Poschlod, P. 2012. Pioneers and perches - promising restoration methods for degraded Renosterveld habitats? Restoration Ecology 20: 18-23.

Henderson, L. 2001. Alien weeds and invasive plants: a complete guide to declared weeds and invaders in South Africa. ARC-PPRI, PPRI handbook No. 12, Pretoria, ZA.

Hobbs, R.J. \& Harris, J.A. 2001. Restoration ecology: repairing the Earth's ecosystems in the new millennium. Restoration Ecology 9: 236-246.

Holmes, P.M. \& Richardson, D.M. 1999. Protocols for restoration based on knowledge of recruitment dynamics, community structure and ecosystem function: perspectives from South African fynbos. Restoration Ecology 7: 215-231.

Holmes, P.M., Richardson, D.M., Esler, K.J., Witkowski, E.T.F. \& Fourie, S. 2005. A decision-making framework for restoring riparian zones degraded by invasive alien plants in South Africa. South African Journal of Science 101: 553-564.

Holmes, P.M., Esler, K.J., Richardson, D.M. \& Witkowski, E.T.F. 2008. Guidelines for improved management of riparian zones invaded by alien plants in South Africa. South African Journal of Botany 74: 538-552.

Hood, W.G. \& Naiman, R.J. 2000. Vulnerability of riparian zones to invasion by exotic vascular plants. Plant Ecology 148: 105114.

Huston, M. 1979. A general hypothesis of species diversity. American Naturalist 1 13: 81-101.

King, E.G. \& Hobbs, R.J. 2006. Identifying linkages among conceptual models of ecosystem degradation and restoration: towards an integrative framework. Restoration Ecology 14: 369-378.

Marchante, H., Freitas, H. \& Hoffmann, J.H. 2011 . Post-clearing recovery of coastal dunes invaded by Acacia longifolia: is duration of invasion relevant for management success? Journal of Applied Ecology 48: 1295-1304.

Moore, M.M., Casey, C.A., Bakker, J.D., Springer, J.D., Fule', P.Z., Covington, W.W. \& Laughlin, D.C. 2006. Herbaceous vegetation responses (1992-2004) to restoration treatments in a ponderosa pine forest. Rangeland Ecology and Management 59: 135-144. 
Mucina, L. \& Rutherford, M.C. 2006. The vegetation of South Africa, Lesotho and Swaziland. Strelitzia 19, South African National Biodiversity institute, Pretoria, ZA.

Nelson, C.R., Halpern, C.B. \& Agee, J.K. 2008. Thinning and burning result in low-level invasion by nonnative plants but neutral effects on natives. Ecological Applications 18: 762-770.

Pretorius, M., Esler, K.J., Holmes, P.M. \& Prins, N. 2008. The effectiveness of active restoration following alien clearance in Fynbos riparian zones and resilience of treatments to fire. South African Journal of Botany 74: 517-525.

Prinsloo, F.W. \& Scott, D.F. 1999. Stream flow responses to the clearing of invasive alien trees from riparian zones from three sites in the Western Cape Province. South African Forestry Journal 185: 1-7.

Pyšek, P., Richardson, D.M., Rejmánek, M., Webster, G.L., Williamson, M. \& Kirschner, J. 2004. Alien plants in checklists and floras: towards better communication between taxonomists and ecologists. Taxon 53: 131-143.

Reinecke, M.K., Pigot, A. \& King, J.M. 2008. Spontaneous succession of riparian Fynbos: is unassisted recovery a viable restoration strategy? South African Journal of Botany 74: 412-420.

Rhoades, J.D. 1982. Cation exchange capacity. In: Page, A.L., Miller, R.H. \& Keeney, D.R. (eds.) Methods of soil analysis, 2nd edition, pp. 149-157. American Society of Agronomy, Madison, WI, US.

Richardson, D.M. \& Van Wilgen, B.W. 2004. Invasive alien plants in South Africa: how well do we understand the ecological impacts? South African Journal of Science 100: 45-52.

Richardson, D.M., Bond, W.J., Dean, W.R.J., Higgins, S.I., Midgley, G.F., Milton, S.J., Powrie, L., Rutherford, M.C., Samways, M.J. \& Schulze, R.E. 2000a. Invasive alien organisms and global change: a South African Perspective. In: Mooney, H.A. \& Hobbs, R.J. (eds.) Invasive species in a changing world, pp. 303-349. Island Press, Washington, DC, US.

Richardson, D.M., Pyšek, P., Rejmánek, M., Barbour, M.G., Panetta, F.D. \& West, C.J. 2000b. Naturalization and invasion of alien plants - concepts and definitions. Diversity and Distributions 6: 93-107.

Richardson, D.M., Holmes, P.M., Esler, K.J., Galatowitsch, S.M., Stromberg, J.C., Kirkman, S.P., Pyšek, P. \& Hobbs, R.J. 2007.
Riparian vegetation: degradation, alien plant invasions, and restoration prospects. Diversity and Distributions 13: 126-139.

Samways, M.J. \& Taylor, S. 2004. Impacts of invasive alien plants on red-listed South African Dragonflies (Odonata). South African Journal of Science 100: 78-80.

Sasikumar, K., Vijayalakshmi, C. \& Parthiban, K.T. 2002. Allelopathic effects of Eucalyptus on blackgram (Phaseolus mungo L.). Allelopathy Journal 9: 205-214.

Schweithem, J., Wirawan, N., Elliott, J. \& Khan, J. 1992. Sulawesi parks program land use and socio-economic survey. Lore Lindu National Park and Morowali Nature Reserve. The Nature Conservancy, Jakarta, ID.

van Andel, J. \& Aronson, J. 2012. Restoration ecology: the new frontier, second edition. Blackwell, Oxford, UK

Van Wilgen, B.W., Le Maitre, D.C. \& Cowling, R.M. 1998. Ecosystem services, efficiency, sustainability and equity: South Africa's working for water programme. Trends in Ecology and Evolution 13: 378.

Van Wilgen, B.W., Khan, A. \& Marais, C. 2011. Changing perspectives on managing biological invasions: insights from South Africa and the working for Water programme. In: Richardson, D.M. (ed.) Fifty years of invasion ecology: the legacy of Charles Elton, pp. 377-393. Wiley-Blackwell, Oxford, UK.

Van Wyk, G.F., Everard, D.A. \& Geldenhuys, C.J. 1995. Forest ecotone development and succession; experimental results and guidelines for forest rehabilitation and protection. Division of Forest Science and Technology (Report FOR-DEA 867) CSIR, Pretoria, ZA.

Vosse, S., Esler, K.J., Richardson, D.M. \& Holmes, P.M. 2008. Can riparian seed banks initiate restoration after alien plant invasion? Evidence from the Western Cape, South Africa South African Journal of Botany 74: 432-444.

Yelenik, S.G., Stock, W.D. \& Richardson, D.M. 2004. Ecosystem impacts of invasive Acacia saligna in South African Fynbos. Restoration Ecology 12: 44-51.

Zar, J.H. 1996. Biostatistical analysis. Prentice Hall, London, UK.

Zhang, D., Zhang, J., Yang, W. \& Wu, F. 2010. Potential allelopathic effect of Eucalyptus grandis across a range of plantation ages. Ecological Research 25: 13-23. 